\title{
Profil Kasus Tuberkulosis Paru di Instalasi Rawat Inap Paru RSUP Dr. M. Djamil Padang Periode 1 Januari 2010 - 31 Desember 2011
}

\author{
M. Gamal Eddin ${ }^{1}$, Oea Khairsyaf ${ }^{2}$, Elly Usman ${ }^{3}$
}

\begin{abstract}
Abstrak
Tuberkulosis (TB) paru merupakan penyakit infeksi menular yang disebabkan Mycobacterium tuberculosis yang masih merupakan masalah kesehatan di dunia dan Indonesia sampai sekarang ini.Penelitian ini adalah penelitian deskriptif analitik dengan menggunakan data sekunder, yaitu rekam medik penderita TB paru. Populasi adalah semua kasus TB paru di Instalasi Rawat Inap Paru RSUP Dr. M. Djamil Padang selama 1 Januari 2010-31 Desember 2011 yang mempunyai data rekam medik lengkap. Perhitungan analitik menggunakan Chi Square dengan $\alpha=0,05$. Penelitian ini bertujuan untuk mengetahui profil kasus tuberkulosis paru di Instalasi Rawat Inap Rumah Sakit Umum Pusat (RSUP) Dr. M. Djamil Padang dari 1 Januari 2010 sampai 31 Desember 2011, yaitu karakteristik, temuan klinis dan laboratorium klinis, komorbid, dan farmakologi TB paru. Jumlah kasus TB paru dari penelitian ini adalah 65 buah. TB paru dengan BTA sputum negatif (60\%) adalah klasifikasi TB paru terbanyak. Laki- laki (72\%), usia 20- 29 tahun $(27 \%)$, pendidikan tamat sekolah lanjut tingkat atas (SLTA)(47\%), pekerjaan rumah tangga (33\%) merupakan karakteristik terbanyak diikuti merokok pada laki- laki (64\%) dan status gizi kurus dengan kekurangan berat badan tingkat berat (53\%). Hasil data analisis berdasarkan Chi Square, didapatkan $X^{2}=2,5$ dengan $\alpha=0,05$, sehingga tidak ada hubungan bermakna antara jenis kelamin dengan hasil pemeriksaan BTA sputum. Terdapat hubungan bermakna antara merokok dengan jenis kelamin $\left(X^{2}=41,6 ; p \leq 0,05\right)$. Sesak nafas $(56 \%)$ merupakan klinis terbanyak dan anemia (66\%), laju endap darah (LED) meningkat (95\%), kadar gula darah sewaktu (GDS) normal (89\%), serum glutamic oxsaloasetic transaminase (SGOT) normal (72\%), dan serum glutamic pyruvic transaminase (SGPT) normal (84\%) merupakan temuan laboratorium klinis terbanyak. Sebanyak $32 \%$ dari 65 buah kasus tidak mempunyai komorbid. Enam komorbid terbanyak adalah efusi pleura (22\%), pneumonia (18\%), diabetes melitus tipe 2 (DM tipe 2) (12\%), pneumotoraks $(10 \%)$, hiponatremia $(9 \%)$, dan penyakit paru obstruktif kronik (PPOK) $(7 \%)$ dan spondilitis $(1 \%)$ dan peritonitis TB (1\%) merupakan TB ekstraparu yang ditemukan dari penelitian ini. RHZE (86\%) dan $\mathrm{RH}(6 \%)$ merupakan regimen obat antituberkulosis (OAT) yang digunakan pada kategori 1 dan RHZES (7\%) pada kategori 2 sehingga kategori 1 (92\%) merupakan klasifikasi kasus TB paru berdasarkan definisi klinis terbanyak.
\end{abstract}

Kata kunci: mycobacterium tuberkulosis, tuberkulosis, tuberkulosis paru

\section{Abstract}

Pulmonary tuberculosis (PTB) is an infection transmitted diseases caused by Mycobaterium tuberculosis which is still be one of the health problems in the world and Indonesia until now. This research is a analytic descriptive that use secondary datas, which is medical records of PTB patients. The populations are all cases of pulmonary TB in Pulmonary Instalations Dr. M. Djamil Padang from 1 January 2010- 31 Desember 2011 which have complete medical record datas. Analytic using Chi Square with $\alpha=0,05$. The aim of this research is to know the profile of pulmonary tuberculosis cases in Pulmonary Instalations Dr. M. Djamil Padang from 1 January 2010 until 31 December 2011, which are characteristic, clinical findings, clinical laboratorium findings, comorbid, and pharmacology of PTB.The amount of cases from this research is 65 cases. PTB with negatif acid-fast bacilii (AFB) (60\%) is the most 
calassification of PTB. Male (72\%), age 20- 29 years old (27\%), senior high school graduated (47\%), unemployed (33\%) are the most characteristic followed by smoke on male (64\%) and severe low body weigh of nutritional status (53\%). Data analyzed resultswith Chi Square results on $X^{2}$ is 2,5 and suggested that statistically there is no relationship between gender and acid- fast bacilii examination $(p>0,05)$. There is significant relationship between smoking history and gender ( $\left.X^{2}=41,6 ; p \leq 0,05\right)$. Shortbreathness (56\%) is the most clinical finding and anemia (66\%), high eritrocytes sedimen rate (ESR) (95\%), normal random blood glucose (89\%), normal serum glutamic oxsaloasetic transaminase (SGOT) (72\%), and normal serum glutamic pyruvic transaminase (SGPT) (84\%) are the most clinical laboratorium findings. A 32\% of 65 cases dont have comorbid. The six most of comorbid are pleural effusion (22\%), pneumonia (18\%), diabetes melitus type $2(12 \%)$, pneumothorax (10\%), hyponatremia (9\%), and chronic obstructive pulmonary disease $(7 \%)$ and spondilits (1\%) and peritonitis TB (1\%) are the extrapulmonary TB found on this research. RHZE (86\%) and RH (6\%) are the regiment of antiTB drugs which is given on 1st category and RHZES (7\%) is given on 2nd category and then 1st category is the most classification of PTB based on clinical definitions.

Keywords: Mycobacterium tuberculosis, tuberculosis, pulmonary tuberculosis

Korespondensi: 1. Pendidikan Dokter FK UNAND (Fakultas Kedokteran, Universitas Andalas Padang), 2. Bagian Pulmonologi, FK UNAND / RSUP Dr. M. Djamil, 3. Bagian Farmakologi FK UNAND Afiliasi Penulis: M. Gamal Eddin, E-mail: mgamal.me@gmail.com, telp : 08126694896

\section{PENDAHULUAN}

Tuberkulosis (TB) paru adalah penyakit infeksi menular yang disebabkan Mycobacterium tuberkulosis dan masih menjadi masalah kesehatan di dunia dan Indonesia, terutama di negara berkembang, dengan lebih dari 9 juta kasus baru di dunia dan sepertiga penduduk dunia telah terinfeksi bakteri ini. ${ }^{1}$ Indonesia menempati peringkat kelima dunia dengan negara penderita TB terbanyak dengan 430.000 kasus baru setiap tahun. Pada tahun 2010, Sumatera Barat belum mencapai angka indikator ke-berhasilan pengendalian TB paru, yaitu $53,1 \%$ dari batas $73 \%{ }^{3}$

Pengobatan terputus, yang terdapat pada golongan sosioekonomi rendah, merupakan faktor risiko terpenting dalam peningkatan angka kejadian TB paru. ${ }^{4}$ Penyakit ini, yang dapat didiagnosis dengan pemeriksaan batang tahan asam (BTA) dari sputum penderita, lebih banyak terdapat pada laki- laki di usia produktif. ${ }^{5}$ Jika penderita TB paru mengalami gejala klinis TB paru, maka dapat menurunkan produktifitas hidup dan dapat diperberat oleh penyakit lain, misalnya HIV/ AIDS atau diabetes mellitus tipe 2, sehingga TB paru dapat mem-pengaruhi penyakit lain, dan sebaliknya. Untuk menunjang diagnosis TB paru, maka dapat dilakukan pemeriksaan laboratorium, berupa pemeriksaan laboratorium hematologi dan kimia klinis, misalnya hemoglobin $(\mathrm{Hb})$, laju endap darah (LED), gula darah sewaktu (GDS), dan serum transaminase untuk memberikan obat anti tuberkulosis (OAT) yang sesuai. ${ }^{6}$

Indonesia telah mempunyai fasilitas diagnostik dan pengobatan TB paru, tetapi masih belum mencakup seluruh fasilitas kesehatan di Indonesia. ${ }^{7}$ Tuber-kulosis (TB) paru menempati urutan pertama terbanyak kasus penyakit paru di RS Dr. M. Djamil Padang. ${ }^{8}$ Oleh karena itu, diperlukan pengetahuan, perhatian, dan kepatuhan ter-hadap pengobatan sehingga dapat melakukan pencegahan dan deteksi dini dalam upaya menyembuhkan penderita dan menurunkan angka kejadian TB paru. Berdasarkan hal tersebut, penelitian ini bertujuan untuk mengetahui profil kasus TB paru di Instalasi Rawat Inap Paru Dr. M. Djamil Padang periode 1 Januari 2010- 31 Desember 2011.

\section{METODE}

Jenis penelitian ini adalah deskriptif analitik secara retrospektif dengan meng-gunakan data sekunder dari buku status rekam medik dan rekam medik penderita yang telah didiagnosis akhir tuberkulosis (TB) paru di Instalasi Rawat Inap Paru dan Instalasi Rekam Medik Dr. M. Djamil Padang dengan populasi semua kasus TB paru di Instalasi Rawat Inap Paru RSUP Dr. M. Djamil Padang selama 1 Januari 2010-30 Juni 2011 yang mempunyai data rekam medik lengkap dan 69 dari 134 kasus tidak mempunyai data rekam medik lengkap sehingga sebanyak 65 kasus yang digunakan dalam penelitian 
ini. Perhitungan analitik, digunakan metode Chi Square dengan $\alpha=0,05$.

Data dikumpulkan dari buku status rekam medik dan rekam medik, kemudian dilakukan evaluasi. Selanjutnya, dilakukan tahap pengolahan data, meliputi tahap persiapan dengan melakukan pemeriksaan kembali kelengkapan data, tahap penyusunan dan perhitungan data sehingga dapat dikelompokkan, dan tahap tabulasi dengan melakukan perhitungan manual dan dianalisis.

\section{HASIL}

Jumlah kasus tuberkulosis (TB) paru di Instalasi Rawat Inap Paru RSUP Dr. M. Djamil Padang dalam periode 1 Januari 2010- 31 Desember 2011 adalah 134 dari 1.145 kasus penyakit paru dan sebanyak 65 tidak mempunyai data rekam medik lengkap.

Tabel 1. Distribusi kasus TB paru berdasarkan BTA sputum

\begin{tabular}{lcr}
\hline BTA Sputum & $\mathbf{n}$ & $\%$ \\
\hline TB Paru BTA Positif & 26 & 40 \\
TB Paru BTA Negatif & 39 & 60 \\
\hline & 65 & 100 \\
\hline
\end{tabular}

Berdasarkan Tabel 1, TB paru BTA negatif mempunyai jumlah lebih banyak, yaitu 39 (60\%) dari 65 kasus TB paru.

Tabel 2. Distribusi kasus TB paru berdasarkan karakteristik TB paru

\begin{tabular}{lcr}
\hline Karakteristik & Distribusi Terbanyak & $\mathbf{n ~ ( \% )}$ \\
\hline Usia & $20-29$ tahun & $18(27,7)$ \\
Jenis Kelamin & Laki- laki & $47(72,3)$ \\
BTA Sputum & Negatif (Laki- laki) & $16(24,6)$ \\
Pendidikan & Sekolah Lanjut Tingkat & $31(47,7)$ \\
& Atas (SLTA) & \\
Pekerjaan & Rumah Tangga & $22(33,8)$ \\
Status Merokok & Merokok (Laki - laki) & $42(64,6)$ \\
Status Gizi & Kurus dengan & $35(33,8)$ \\
& Kekurangan Berat & \\
& Badan Berat & \\
\hline
\end{tabular}

Pada Tabel 2 terlihat bahwa penderita TB paru lebih banyak terdapat pada laki- laki $(72,3 \%)$ di usia 20- 29 tahun (27,7\%).BTA sputum negatif banyak terdapat pada laki- laki. Pendidikan dan pekerjaan terbanyak adalah SLTA (47,7\%) dan rumah tangga (33,8\%). Merokok (64,6\%) lebih banyak dibandingkan tidak merokok dan banyak terdapat pada laki- laki. Kurus dengan kekurangan berat badan berat adalah tingkat status gizi terbanyak (33,8\%).

Tabel 3. Distribusi kasus TB paru berdasarkan klinis

\begin{tabular}{lrr}
\hline Keluhan Utama & $\mathbf{n}$ & $\%$ \\
\hline Sesak Nafas & 37 & 56,9 \\
Batuk Darah & 15 & 23,1 \\
Malaise & 6 & 9,2 \\
Batuk & 4 & 6,1 \\
Demam & 1 & 1,5 \\
Muntah & 1 & 1,5 \\
Nyeri Dada & 1 & 1,5 \\
\hline
\end{tabular}

Berdasarkan Tabel 3, sesak nafas $(56,9 \%)$, batuk darah $(23,1 \%)$, dan malaise $(9,2 \%)$ merupakan keluhan utama penderita TB paru terbanyak.

Tabel 4. Distribusi kasus TB paru berdasarkan pemeriksaan laboratorium

\begin{tabular}{lcr}
\hline Pemeriksaan Laboratorium & $\begin{array}{c}\text { Distribusi } \\
\text { Terbanyak }\end{array}$ & n (\%) \\
& & \\
\hline Hemoglobin (Hb) & Anemia & $43(66,2)$ \\
Leukosit & Meningkat & $36(55,4)$ \\
Laju Endap Darah (LED) & Meningkat & $62(95,4)$ \\
Gula Darah Sewaktu (GDS) & Normal & $58(89,2)$ \\
Serum Glutamic Oxasaloasetic & Normal & $47(72,3)$ \\
Transaminase (SGOT) & & \\
Serum Glutamic Pyruvic & Normal & $55(84,6)$ \\
Transaminase (SGPT) & & \\
& & \\
\hline
\end{tabular}

Berdasarkan Tabel 4, terlihat anemia (66,2\%), jumlah leukosit meningkat (leukositosis) (55,4\%), dan LED meningkat $(95,4 \%)$ adalah pemeriksaan laboratorium hematologi klinis terbanyak, sedangkan kadar GDS normal (89,2\%), SGOT (72,3\%) dan SGPT normal $(84,6 \%)$ merupakan pemeriksaan kimia klinis terbanyak. 
Tabel 5. Distribusi kasus TB paru berdasarkan komorbid

\begin{tabular}{lrr}
\hline \multicolumn{1}{c}{ Komorbid } & $\mathbf{n}$ & $\%$ \\
\hline Efusi Pleura & 15 & 22,7 \\
Pneumonia & 12 & 18,2 \\
Diabetes Melitus tipe 2 & 8 & 12,1 \\
Pneumotoraks & 7 & 10,6 \\
Hiponatremia & 6 & 9,1 \\
Penyakit Paru Obstruktif Kronik & 5 & 9,1 \\
Gagal Nafas & 2 & 3,1 \\
Hipoalbuminemia & 2 & 3,1 \\
Septikemia & 2 & 3,1 \\
Bronkiektasis & 1 & 1,5 \\
Empyema & 1 & 1,5 \\
Infeksi Oporunitis & 1 & 1,5 \\
Karsinoma Bronkogenik & 1 & 1,5 \\
Cor Pulmonale Kronik & 1 & 1,5 \\
Spondilitis TB & 1 & 1,5 \\
Peritonitis TB & 1 & 1,5 \\
\hline
\end{tabular}

Efusi pleura (22,7\%), pneumonia (18,2\%), diabetes mellitus tipe $2(12,1 \%)$, penumotoraks $(10,6 \%)$, dan hiponatremia $(9,1 \%)$ merupakan komorbid terbanyak dari penelitian ini.

Tabel 6. Distribusi kasus TB paru berdasarkan regimen obat antituberkulosis

\begin{tabular}{llrr}
\hline \multicolumn{1}{c}{ Farmakologi } & $\mathbf{n}$ & $\%$ \\
\hline Rifampisin, Isoniazid, & Pirazinamid, & 56 & 84,6 \\
Etambutol (RHZE) & & 4 & 6,2 \\
Rifampisin, Isoniazid (RH) & & & \\
Rifampisin, Isoniazid, & Pirazinamid, & 5 & 7,7 \\
Etambutol (RHZE) & & & \\
\hline & & 65 & 100
\end{tabular}

Berdasarkan penelitian ini, regimen $\mathrm{RHZE}$ (rifampisin $(R)$, isoniazid $(H)$, pirazinamid $(Z)$, etambutol $(E)(86 \%)$ merupakan regimen pengobatan yang digunakan pada pengobatan tahap intensif dari kasus TB paru kategori 1 dan $\mathrm{RH}$ (6\%) merupakan regimen pengobatan yang digunakan pada tahap lanjutan dari kasus TB paru kategori 1. Kasus TB paru kategori 2 menggunakan regimen RHZES (rifampisin $(R)$, isoniazid $(H)$, pirazinamid $(Z)$, etambutol $(E)$, streptomisin (S))(7\%)

\section{PEMBAHASAN}

Penderita TB paru dengan BTA sputum positif memberikan penularan lebih tinggi karena penyakit ini bersifat aktif. ${ }^{7}$ Berdasarkan tabel 2 , tidak didapatkan hubungan bermakna antara jenis kelamin dengan hasil pemeriksaan BTA sputum $\left(X^{2}=2,5\right.$ dengan $\alpha=0,05$, sehingga $p>0,05$.

Penderita TB paru lebih banyak terdapat pada laki- laki di usia produktif yang sesuai dari Tabel 2. Kebiasaan hidup merokok dan aktifitas tinggi lebih sering terjadi pada laki- laki di usia tersebut. Pendidikan SLTA $(47,7 \%)$ dan tidak bekerja (rumah tangga)(33,8\%) mempunyai jumlah terbanyak dan hal tersebut sesuai dengan faktor risiko TB paru utama, yaitu sosioekonomi. Penderita TB paru umumnya mempunyai kebiasaan hidup merokok dan lebih banyak terdapat pada laki- laki, sehingga dapat meningkatkan risiko TB paru. ${ }^{9}$ Status gizi kurus dengan kekurangan berat badan berat (35 kasus) merupakan status gizi terbanyak dari penelitian ini berhubungan dengan semua faktor risiko terjadinya TB paru.

Berdasarkan Tabel 3, sesak nafas, batuk darah, dan malaise merupakan gejala klinis yang umumnya terdapat pada TB paru pascaprimer. Pembentukan jaringan parut di bronkus oleh kavitas yang menutup di bronkus dapat menimbulkan sesak nafas sedangkan malaise disebabkan sitokin yang dilepaskan makrofag aktif. ${ }^{12}$

Tabel 4 memperlihatkan anemia dapat ditemukan pada 40 - 60\% penderita TB paru. Anemia pada penderita TB paru disebabkan oleh penekanan eritropoesis di sum- sum tulang dan penurunan penggunaan besi. ${ }^{13}$ Uzun, Turgut dan Erkan (2005) menyatakan bahwa sekitar 40\% - 60\% leukositosis terdapat pada TB paru. ${ }^{13}$ Hungund et al (2012) menyatakan bahwa >95\% kasus TB paru mempunyai LED meningkat dan dapat digunakan untuk mengetahui progresivitas, lama, prognosis, dan evaluasi pengobatan. ${ }^{14}$ Gula darah sewaktu (GDS), SGOT, dan SGPT normal mempunyai jumlah terbanyak dari penelitian ini. Infeksi Mycobacterium tuberculosisyang aktifdan akut dapat memperburuk kontrol gula dan proses peradangan oleh bakteri TB dapat melepaskan enzim hati. ${ }^{10}$

Ajmal (2011) menyatakan bahwa efusi pleura 
(penimbunan cairan di dalam rongga pleura) merupakan salah satu dari komplikasi TB paru terbanyak sedangkan Shamae et al (2011) mengungkapkan bahwa pneumotoraks (terdapatnya udara dalam rongga pleura) merupakan salah satu dari 2 komplikasi TB paru terbanyak. ${ }^{11,15}$ DM tipe 2 dapat meningkatkan risiko TB paru akibat penurunan imun tubuh yang berkolerasi dengan fungsi T-helper1 (Th1) dan makrofag menurun. ${ }^{10}$ Sindrom sekresi antidiuretik hormon (ADH) yang tidak tepat (SIADH (Syndrome of Inappropriate Anti-diuretik Secretion)) merupakan salah satu penyebab hiponatremia pada TB paru. ${ }^{16}$ Blankley et al (2010) menyatakan dari sebuah penelitian bahwa $24 \%$ dari 242 penderita TB paru mengalami hiponatremia. ${ }^{17}$

Pengobatan TB paru yang membutuhkan obat kombinasi dan waktu yang lama ternyata memberikan efek samping multisistemik yang berbahaya sehingga kepatuhan dalam pengobatan sangat dibutuhkan supaya tidak menambah lama masa pengobatan. ${ }^{18}$ Dari Tabel 6, regimen RHZE (rifampisin $(R)$, isoniazid $(H)$, pirazinamid $(Z)$, etambutol $(E)(86 \%)$ merupakan regimen pengobatan yang digunakan pada pengobatan tahap intensif dan $\mathrm{RH}(6 \%)$ merupakan regimen pengobatan yang digunakan pada tahap lanjutan dari kasus TB paru kategori 1.

\section{KESIMPULAN}

TB paru BTA sputum negatif lebih banyak dibandingkan TB Paru BTA positif, tetapi tidak ada hubungan bermakna antara jenis kelamin dengan hasil pemeriksaan BTA sputum $(p>0,05)$. Usia 20- 29 tahun, laki- laki, pendidikan tamat sekolah lanjut tingkat atas (SLTA), pekerjaan rumah tangga, merokok, dan status gizi kurus dengan kekurangan berat badan berat merupakan karakteristik penderita TB paru dari penelitian ini serta terdapat hubungan yang bermakna antara merokok dengan jenis kelamin $(p \leq 0,05)$. Penemuan laboratorium klinis terbanyak adalah anemia, laju endap darah (LED) meningkat, gula darah sewaktu (GDS) normal, serum glutamate oxaloacetic transaminase (SGOT) normal, dan serum glutamate pyruvic transaminase (SGPT) normal. Efusi pleura, pneumonia, diabetes mellitus (DM) tipe 2, penumotoraks, dan hiponatremia merupakan komorbid terbanyak dari penelitian ini. Penderita TB paru kategori 1 merupakan kategori terbanyak dengan regimen pengobatan yang digunakan adalah $\mathrm{RHZE}$ (rifampisin $(\mathrm{R})$, isoniazid $(\mathrm{H})$, pirazinamid $(\mathrm{Z})$, etambutol $(\mathrm{E})$ ) pada tahap intensif dan $\mathrm{RH}$ (rifampisin dan isoniazid) pada tahap lanjutan.

\section{DAFTAR PUSTAKA}

1. Amin Z, Bahar A. Tuberkulosis paru. Dalam: A W Sudoyo, B Setiyohadi, I Alwi, M Simadibrata K, S Setiati, editor (penyunting). Buku ajar ilmu penyakit dalam. Edisi ke- 5. Jakarta: Internal Publishing; 2010; vol.3. hlm. 2230-9.

2. Lawn SD, Zumla Al. 2011. Tuberculosis. The Lancet. 2011;378(9785):52 - 72

3. Dinas Kesehatan Provinsi Sumatera Barat. Profil pembangunan kesehatan Kabupaten Agam tahun 2010.2011.

4. Elamin El, Ibrahim MIM, Sulaiman SAS, Muttalif AR. Cost of Illness of tuberculosis in Penang, Malaysia. Pham World Sci.2008;30:281 - 286.

5. Dye C. Global epidemiology of tuberculosis. The Lancet. 2006;367(9514):938- 40.

6. Dooley KE, Chaisson RE. Tuberculosis and diabetes mellitus: Convergence of Two Epidemics. The Lancet Infectious Diseases. 2009;9(2):737-74.

7. Aditama TY. Tuberkulosis, masalah dan perkembangannya. Semijurnal Farmasi dan Kedokteran Ethical Digest. 2008;57:61-72.

8. Roni. Profil penyakit paru RSUP $\mathrm{Dr} M$ Djamil Padang tahun 2009-2010 (karya ilmiah). Padang: Fakultas Kedokteran Universitas Andalas; 2012.

9. Wijaya AA. Merokok dan tuberkulosis. Jurnal Tuberkulosis Indonesia. 2012;8:18- 23.

10. Jepsen DF, Range N, PrayGod G, Jeremiah K, Jepsen MF, Aabye MG, et al. Diabetes is a risk factor for pulmonary tuberculosis: a case -control study from Mwanza, Tanzania. Plosone. $2011 ; 6(8): 1-5$.

11. Ajmal B. Manajement of tuberculous pleural effusion. J Biomed Sci and Res. 2011;3(1):302-7.

12. Maitra A, Kumar V. Paru dan saluran nafas atas. Dalam: Huriawati $H$, Nurwany $D$, Nanda W, editor (penyunting). Buku Ajar Patologi Robbins.. Edisi ke- 7. Jakarta: EGC. 2007.hlm.509- 70. 
13. Uzun O, Turgut M, Erkan L. Two unsual presentations of tuberculosis. Ann Saudi Med. 2005;25(6):496- 500.

14. Hungund BR, Sangolli SS, Bannur HB, Malur PR, Pilli GS, Chavan RY, et al. Blood and bone marrow findings in tuberculosis in adults - a cross sectional study. Al Ameen J Med Sci. 2012;5(4):362- 6.

15. Shamaei M, Tabarsi P, Pojhan S, Ghorbani L, Baghaei $\mathrm{P}$, Marjani $\mathrm{M}$, et al. Tuberculosis Associated Secondary Pneumothorax: a Retrospective Study of 53 Patients. Respiratory Care. 201;56(3):298- 302.

16. Wilson LM. Gangguan volume, osmo-lalitas, dan elektrolit cairan. Dalam: HartantoH, Wulansari P, N
Susi, Mahani DA, editor (penyunting). Patofisiologi: Konsep Klinis Proses-Proses Penyakit. Edisi ke-6. Jakarta: EGC; 2005: vol.1. hlm.328-72.

17. Blankley S, Rollason C, Graham B. Hyponatremia in tuberculosis. 2010. London.

18. Melindawaty, Tanjung A, Pelly R. Beberapa aspek penderita tuberkulosis paru yang berobat jalan di poliklinik pulmonologi bagian ilmu penyakit dalam RS Dr Pirngadi Medan. Dalam: Acang N, Nelwan $\mathrm{RHH}$, Syamsuri W, Utama AC, Masrul, editor (penyunting). ACTA MEDICA INDONESIANA. Padang: Percetakan Pancaran IImu. 1996; 28(5): $1438-43$. 